\title{
ANALISIS EKSPOR LIDAH BUAYA (ALOE VERA) KALIMANTAN BARAT" (STUDI KASUS EKSPOR KE NEGARA MALAYSIA)
}

\author{
Zulka Sapta Dilla \\ saptadilla@yahoo.co.id \\ Politeknik Putra Bangsa Pontianak
}

\begin{abstract}
The development of non-oil and gas exports, a very important role in the development of the national economy with strategic policies that need to be improved for West Kalimantan Province is the commodity of Aloe Vera, which is one of the agricultural products that has competitiveness in the international market. So that government and private investment continues to be encouraged to increase the production and quality of aloe vera commodities. The results show that the value of the quantity of aloe vera export to Malaysia shows that there is a positive relationship. Whereas to see whether the results of the research model estimation are theoretically meaningful and are statistically significant, a "priori" economic criteria test and statistical criteria test will be conducted. The economic "a priori" criteria test is done by comparing the suitability of the sign between the regression parameter coefficients and the theory in question. If the regression parameter coefficient is in accordance with the principles of economic theory, then the parameter has passed the test.
\end{abstract}

Keywords: Interest Rates, Demand, and Aloe Vera.

\section{PENDAHULUAN}

Setelah krisis pada tahun 1997, ekspor nonmigas (non-minyak dan gas) Indonesia menurun pada tahun 1998 dan 1999. Dalam tahun 2000 ekspor meningkat tajam terutama didorong dengan permintaan eksternal yang kuat. Resesi dunia yang terjadi tahun 2001 dengan pertumbuhan ekonomi dunia sekitar 2,2\% mengakibatkan ekspor non-migas menurun sekitar $10 \%$. Meskipun perekonomian dunia telah pulih dengan pertumbuhan sekitar 3,2\%, ekspor non-migas hanya meningkat $1,5 \%$ (BAPPENAS, 2003:I-17).

Untuk ekspor pertanian setelah mencapai puncaknya pada tahun 1998, yaitu sebesar US $\$ 3,7$ miliar, nilai ekspor hasil pertanian berfluktuasi dengan kecendrungan menurun. Pada tahun 2002 ekspor hasil pertanian hanya mencapai US\$2,6 miliar. Dilihat dari volumenya, ekspor hasil pertanian pada tahun 1997 berjumlah 1,8 juta ton justru meningkat pada tahun 1998 yaitu mencapai 3,2 juta ton. Pada tahun 1999, 2000, 2001 dan 2002 berturut-turut 2,4 juta ton, 2,0 juta ton, 2,2 juta ton dan 1,9 juta ton. Dalam tahun 2004, kinerja ekspor non-migas harus dapat ditingkatkan untuk mendorong pertumbuhan ekonomi. Berbagai permasalahan yang menghambat peningkatan ekspor non-migas harus dapat dihapuskan. Untuk meningkatkan kinerja ekspor non-migas perlu dilakukan upaya untuk meningkatkan kualitas komoditi, diversifikasi produk, dan perluasan pasar ekspor. Selama ini, pasar komoditi ekspor nasional hanya mengarah pada pasar-pasar tradisional seperti Amerika Serikat, Jepang, dan Singapura sebagai negara tujuan ekspor terbesar (BAPPENAS, 2003:IV-13).

Tabel 1.

Perkembangan Nilai Ekspor

Migas dan Non-migas Indonesia, 1995-2002 (dalam juta US\$)

\begin{tabular}{|c|c|c|c|c|c|}
\hline Tahun & \multicolumn{2}{|c|}{ Migas } & \multicolumn{2}{c|}{ Non-Migas } & Total Nilai \\
Anggaran & Nilai & \%Total & Nilai & \%Total & Ekspor \\
\hline 1995 & $10.464,4$ & 23,0 & $34.953,6$ & 77,0 & $45.418,0$ \\
1996 & $11.721,8$ & 23,5 & $38.093,0$ & 76,5 & $49.814,8$ \\
1997 & $11.622,5$ & 21,7 & $41.821,1$ & 78,3 & $53.443,6$ \\
1998 & $7.872,3$ & 16,1 & $40.975,3$ & 83,9 & $48.847,6$ \\
1999 & $9.792,2$ & 20,1 & $38.875,2$ & 79,9 & $48.665,4$ \\
2000 & $14.366,6$ & 23,1 & $47.757,4$ & 76,9 & $62.124,0$ \\
2001 & $12.636,3$ & 22,4 & $43.684,6$ & 77,6 & $56.320,9$ \\
2002 & $12.112,7$ & 21,2 & $45.046,1$ & 78,8 & $57.158,8$ \\
\hline
\end{tabular}

Dari tabel 1 dapat dilihat ekspor non-migas menunjukan kecendrungan yang meningkat dari tahun ke tahun dan memegang peranan penting di dalam total ekspor Indonesia, walaupun pada tahun 1998 dan 1999 mengalami penurunan. Hal ini disebabkan oleh terjadinya krisis ekonomi Indonesia. Oleh sebab itu, ekspor non-migas 
memegang peranan penting bagi perkembangan perekonomian Indonesia.

Adanya perkembangan ekspor non-migas, peranan yang sangat penting dalam perkembangan perekonomian nasional dengan kebijakkan startegis yang perlu dilakukan untuk Propinsi Kalimantan Barat maka ditingkatkan adalah komoditi Lidah Buaya (Aloe Vera) yang merupakan salah satu produk pertanian yang mempunyai daya saing di pasar internasional.

Lidah buaya merupakan tanaman yang sekulen atau tanaman yang banyak mengandung air dan pada awalnya diusahakan dalam pot oleh penduduk kota Pontianak sebagai tanaman hias dan mencuci rambut (shampo).

Keunggulan lain yang dimiliki tanaman lidah buaya adalah belum ada hama dan penyakit, serta masa panen lidah buaya dapat ditunda beberapa saat sambil menunggu permintaan pasar.

Komoditi lidah buaya merupakan salah satu komoditi unggulan daerah yang memiliki keunggulan komperatif dan kompetitif. Dimana wilayah Kota Pontianak merupakan daerah dengan luas lahan tanaman lidah buaya yang ditanam adalah 130 Hektar dan sedang dikembangkan lagi sebanyak 800 Hektar sehingga produksi diperkirakan terbesar di Indonesia. Prospek pengusahaan tanaman ini juga ditunjang dengan kenyataan bukti manfaat dan kegunaan lidah buaya itu sendiri serta permintaan pasar yang cukup besar terhadap komoditas tersebut. Ekspor lidah buaya dari Kalimantan Barat (Pontianak) ke Hongkong, Singapura, Taiwan dan Korea Selatan serta Malaysia menunjukan permintaan yang terus meningkat setiap tahunnya. Untuk jelasnya realisasi ekspor lidah buaya dapat dilihat dari tabel 1.2 berikut ini:

Tabel 2.

Ekspor Lidah Buaya (Aloe Vera)

Kalimantan Barat 2000 - 2003

\begin{tabular}{|c|c|c|c|c|c|c|}
\hline \multirow[b]{2}{*}{ No } & \multicolumn{3}{|c|}{ Periode tahun 2000-2001 } & \multicolumn{3}{|c|}{ Periode tahun 2002-2003 } \\
\hline & Tujuan & \begin{tabular}{|c|} 
Jumlah \\
(Ton)
\end{tabular} & $\begin{array}{c}\text { Persentase } \\
(\%)\end{array}$ & Tujuan & $\begin{array}{l}\text { Jumlah } \\
\text { (Ton) }\end{array}$ & $\begin{array}{c}\text { Persentase } \\
(\%)\end{array}$ \\
\hline 1. & Malaysia & 518,69 & 41,12 & Malaysia & 754,73 & 48,43 \\
\hline 2. & Hongkong & 373,42 & 29,60 & Hongkong & 233,83 & 15,01 \\
\hline \multirow[t]{2}{*}{3.} & Singapura & 369,44 & 29,28 & Singapura & 569,76 & 36,56 \\
\hline & Jumlah & 1261,55 & 100,00 & Jumlah & 1558,32 & 100,00 \\
\hline
\end{tabular}

Dari kenyataan tersebut di atas maka penelitian ini ditujukan untuk mengetahui faktor-faktor yang mempengaruhi kuantitas ekspor lidah buaya (Aloe Vera) Kalimantan Barat ke Malaysia.
Berdasarkan uraian yang telah dikemukakan pada latar belakang maka yang menjadi masalah dalam penelitian ini adalah bagaimana harga luar negeri, harga luar negeri sebelumnya, nilai tukar mata uang asing (kurs) dan ekspor sebelumnya mempengaruhi kuantitas ekspor lidah buaya Kalimantan Barat ke Malaysia.

\section{TINJAUAN TEORETIS}

Pembangunan masyarakat merupakan suatu proses berkelanjutan dan berkesinambungan. Pembangunan Indonesia dalam jangka panjang dibidang ekonomi merupakan penggerak utama pembangunan, sejalan dengan peningkatan kualitas sumber daya manusia dan didorong untuk saling memperkuat, saling terkait dan terpadu dengan pembangunan bidang lainnya.

Pembangunan pertanian dalam Pelita VI bertujuan mengwujudkan pertanian yang tangguh dan berkelanjutan. Langkah-langkah yang ditempuh antara lain dengan meningkatkan kegiatan intensifikasi, ekstensifikasi, diversifikasi dan peremajaan perkebunan yang sesuai dengan kondisi petani, tanah dan iklim. Pola pembangunan yang diterapkan adalah swadaya dan pembinaan perkebunan besar. Komoditas yang dikembangkan salah satunya adalah komoditi lidah buaya (Aloe Vera).

Teori perdagangan internasional dapat digolongkan kedalam dua kelompok, yakni teori klasik dan teori modern. Teori klasik yang umum dikenal adalah teori Keunggulan Absolut dari Adam Smith, teori Keunggulan Relatif atau Komparatif dari Mill, dan teori Biaya Relatif dari David Ricardo. Sedangkan, teori Porporsi intensitas penggunaan faktor pendukung dari Hecksher dan Ohlin dalam ekonomi internasional disebut sebagai teori modern (Tambunan, 2001:122).

\section{Teori Klasik}

Teori Keunggulan Absolut dari Adam Smith sering disebut sebagai teori murni perdagangan internasional. Dasar teori ini adalah bahwa suatu negara akan melakukan spesialisasi dan ekspor terhadap suatu jenis barang tertentu di mana negara tersebut memiliki keunggulan absolut (absolute advantage) dan tidak memproduksi atau melakukan impor terhadap jenis barang lain di mana negara tersebut tidak mempunyai keunggulan absolut (absolute disadvantage) terhadap negara lain yang memproduksi barang sejenis.

\section{Modern: Teori H-O}

Teori Hecksher dan Ohlin (H-O) disebut juga dengan teori proporsi intensitas faktor (factor 
proportion theory) atau teori ketersediaan faktor (factor endowment theory). Dasar pemikiran dari teori ini adalah bahwa perdagangan internasional, misalnya, antara Indonesia dan Amerika Serikat terjadi karena opportunity costs berbeda antara dua negara tersebut.

\section{Teori Siklus Produk (Product Cycle Theory)}

Dasar pemikiran dari teori ini adalah mengikuti perubahan waktu, setiap produk atau suatu industri akan melalui proses (bisa jangka panjang atau jangka pendek) dari tahap perkembangan (inovasi) hingga tarap kejenuhan (maturity) dan tahap penurunan produksi, selama kondisi-kondisi yang mempengaruhi proses produksi dan location requirements berubah terus secara sistematis. Siklus produksi terdiri dari 4 (empat) tahap. Tahap pertama adalah tahap inovasi atau produk baru, yakni awal mulanya suatu produk (dan proses produksinya) ditemukan atau dikembangkan.

Tahap kedua disebut tahap perluasan (pertumbuhan) volume produksi. Pada tahap ini permintaan baik yang bersumber dari dalam negeri maupun internasional meningkat, dan produk tersebut juga mulai di ekspor ke LDC.

Tahap ketiga adalah tahap kejenuhan pasar (maturity), yakni dimana produk dan proses produksinya telah mencapai kejenuhan pada tingkat yang tinggi dan market saturation meningkat.

Tahap keempat adalah di mana kegiatan produksi di DC menurun, karena persaingan yang semakin kuat dari LDC, yang pada akhirnya proses produksi seluruhnya pindah dari DC ke LDC (Tambunan, 2001:130)

\section{Ekspor}

Pengertian ekspor dalam perdagangan internasioanal adalah keluarnya barang-barang dan jasa-jasa ke suatu negara, jadi ekspor merupakan keluarnya barang-barang dan jasa-jasa (Simamora, 1990:134).

Faktor-faktor yang menimbulkan kemunduran sektor ekspor adalah perubahan permintaan di luar daerah tersebut, habisnya cadangan kekayaan alam dan perubahan teknologi yang merubah posisi input. Perubahan Harga dan Kuantitas.

Teori laba-laba (cobweb theory) menjelaskan tentang penyebab tidak terjadinya keseimbangan sehingga harga yang terbentuk tidak pernah mencapai posisi yang diinginkan oleh produsen atau konsumen. Misalnya pada suatu waktu produsen memperkirakan tingkat harga akan mencapai $\mathrm{P}_{1}$ Pada tingkat ini produsen memandang tingkat harga sangat menguntungkan, sehingga ia berhasrat akan memperbesar penawaran. Apabila pada periode berikutnya ia merealisasikan keinginannya meningkatkan penawaran, maka penawaran di pasar akan meningkat melebihi permintaannya. Akibat penawaran lebih besar dari pada permintaan maka pada periode tersebut akan terjadi penurunan harga bukan seperti yang diinginkan produsen sampai $\mathrm{P}_{1}$ melainkan turun menjadi $\mathrm{P}_{0}$.

Pada harga tingkat $\mathrm{P}_{0}$, produsen beranggapan bahwa tingkat harga ini tidak menguntungkan bagi mereka, sehingga mengurangi minat mereka untuk berproduksi. Keenganan produsen ini ditujukan dengan kuantitas yang ditawarkan hanya sebesar $\mathrm{Q}_{0}$, padahal jumlah yang diminta sebanyak $\mathrm{Q}_{1}$. Akibat penawaran lebih kecil dari pada permintaan maka tingkat harga akan naik kembali pada $\mathrm{P}_{1}$. Demikian proses ini berlanjut dari satu periode ke periode berikutnya, sehingga hubungan antara kenaikan dan penurunan harga dapat digambarkan seperti jaring laba-laba pada Gambar 2.1 berikut ini :

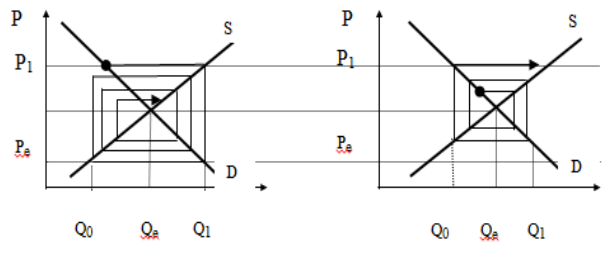

(a)

(b)

(Sumber: Suhartati, 2002:32)

\section{Gambar .1 Model Cobweb}

Pada Gambar 1 (a) perbedaan harga yang terjadi semakin kecil sehingga keseimbangan semakin didekati, sedangkan pada Gambar 2.2 (b), keseimbangan semakin sulit dicapai bahkan perbedaan harga semakin hari semakin bertambah besar (Suhartati, 2002:32).

Mengenai gerakkan harga dan kuantitas dengan memasukkan unsur waktu (model dinamis). Misalnya waktu yang digunakan 1 (Satu) tahun dengan anggapan jumlah barang yang diproduksi tersebut sebagai fungsi dari harga barang tahun sebelumnya. Terlihat adanya rentang waktu (time lag) antara reaksi waktu dan perubahan-perubahan harga, sehingga fungsi penawaran yang "ketinggalan" (lagged) dapat dirumuskan sebagai berikut (Chiang, 1984:441):

Di mana:

$$
\mathrm{Q}_{\mathrm{t}+1}^{\mathrm{S}}=\mathrm{f}(\mathrm{Pt})
$$

$\mathrm{Q}=$ kuantitas

$\mathrm{S}=$ penawaran

$\mathrm{t}+1=$ tahun yang akan datang

$\mathrm{P}=$ harga

$\mathrm{t}=$ tahun sekarang 
Maka jumlah barang yang ditawarkan pada periode waktu yang akan datang ditentukan oleh harga beberapa tahun ini, atau jumlah barang yang ditawarkan. Untuk permintaan juga demikian

$$
\begin{aligned}
& Q^{D_{t+1}}=f(P t) \\
& Q=\text { kuantitas } \\
& D=\text { permintaan } \\
& t+1=\text { tahun yang akan datang } \\
& P=\text { harga } \\
& t=\text { tahun sekarang }
\end{aligned}
$$

Keseimbangan harga pada setiap tahun terjadi kalau $\mathrm{Q}_{\mathrm{D}}=\mathrm{Q}_{\mathrm{s}}$. Sehingga untuk setiap tahun dianggap bahwa penawaran inelastis sempurna dan sama dengan jumlah yang diproduksi.

Sehubungan dengan perilaku permintaan dan penawaran dalam situasi disequilibrium, seandainya produsen menentukan keputusan outputnya berdasarkan harga pasar yang berlaku pada periode yang lalu, maka $\mathrm{Q}$ periode lalu dapat dianggap sebagai konstanta yang tetap jumlahnya. Dengan menganggap tidak ada reaksi masa kini, maka dapat digunakan analisis harga periode waktu yang sangat singkat (very short run).

Nilai Tukar Mata Uang Asing (Kurs)

Bahwa untuk mengukur nilai uang dapat digunakan dua cara yaitu internal value of money dan external value of money. Yang biasa digunakan adalah external value of money, yaitu kemampuan uang untuk ditukar dengan valuta asing. Dengan kata lain nilai uang suatu negara tergantung dari tinggi rendahnya kurs valuta asing negara tersebut dengan negara lain.

Kurs valuta asing merupakan besarnya jumlah suatu mata uang negara tertentu yang diperlukan untuk memperoleh satu unit valuta asing tersebut.

\section{METODE PENELITIAN}

Penelitian ini menggunakan data sekunder yang diperoleh dari Badan Pusat Statistik (BPS) Indonesia, International Financial Statistic (IFS), Bank Indonesia (BI), Dinas Urusan Pangan Kalimantan Barat dan Aloe Vera Center Pontianak serta berbagai data yang dipublikasikan melalui tulisan ilmiah, jurnal dan studi kepustakaan yang terkait.

Model analisis yang digunakan dalam penelitian ini adalah regresi linier berganda (multiple linier regression) (Sujana, 1992:347) dengan menggunakan tiga variabel bebas dan satu variabel terikat, dengan formulasi sebagai berikut:

$\mathrm{Y}=\alpha+\Sigma \beta_{\mathrm{i}} \mathrm{X}_{\mathrm{i}}+\mu$

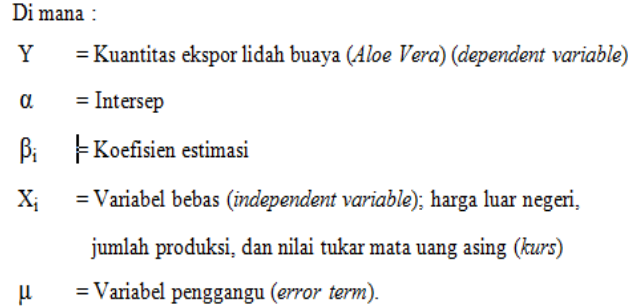

Dalam hal ini fungsi nilai ekspor lidah buaya (Aloe Vera) dalam bentuk dinamis dapat dirumuskan sebagai berikut:

$E_{t}=f\left(H_{t}^{f}, H t-1, K t, K_{t-1}\right)$

$$
\begin{aligned}
& \text { Di mana: } \\
& \mathrm{E}_{\mathrm{t}} \quad=\text { Kuantitas ekspor lidah buaya pada triwulan ke } \mathrm{t} \\
& \mathrm{H}_{\mathrm{t}}^{\mathrm{f}} \quad=\text { Harga lidah buaya di luar negeri pada triwulan ke } \mathrm{t} \\
& \mathrm{H}_{\mathrm{t}-\mathrm{l}}^{\mathrm{f}}=\text { Harga lidah buaya sebelumnya di luar negeri pada triwulan ke } \mathrm{t} \\
& \mathrm{K}_{\mathrm{t},} \quad=\text { Nilai tukar mata uang asing (kurs) pada triwulan ke } \mathrm{t} \\
& \mathrm{K}_{\mathrm{t}-\mathrm{l}}, \quad=\text { Nilai tukar mata uang asing (kurs) sebelumnya pada triwulan ke } \mathrm{t}
\end{aligned}
$$

\section{Perkembangan Variabel Penelitian}

Kuantitas ekspor merupakan volume suatu barang yang diproduksi dan secara fisik diangkut serta dijual ke pasar luar negeri. Perkembangan kuantitas ekspor lidah buaya Kalimantan Barat ke Malaysia sejak kurun waktu tahun 2000 sampai dengan 2003 per bulan dapat dilihat pada tabel 1 .

Dari tabel 1 dapat dilihat rata-rata kuantitas ekspor lidah buaya per bulan tahun 2000 adalah 23,62 ton, tahun 2001 per bulan rata-rata adalah 19,60 ton, tahun 2002 per bulan rata-rata adalah 27,88 ton dan tahun 2003 per bulan rata-rata adalah 35,01 ton.

Hal ini menunjukkan bahwa kuantitas ekspor lidah buaya Kalimantan Barat ke Malaysia rata-rata per bulan pada tahun 2002 adalah 27,88 ton mengalami kenaikkan bila dibandingkan dengan tahun 2000 adalah 23,62 ton dan 2001 adalah 19,60 ton sedangkan pada tahun 2003 adalah 35,01 ton mengalami kenaikan. Adapun penyebab adanya kenaikan kuantitas ekspor yang cukup tinggi per bulan pada tahun 2002 dan 2003 disebabkan kebutuhan didalam negeri Malaysia untuk bahan baku industri lidah buaya mengalami peningkatan yang ditandai dengan harga lidah buaya di pasar Malaysia meningkat.

Perkembangan Harga Ekspor 
Perkembangan harga ekspor lidah buaya disini dilihat dari perkembangan harga lidah buaya yang berada di Malaysia dalam bentuk uang Dollar Amerika (US\$). Perkembangan rata-rata harga ekspor lidah buaya per bulan dari tahun 2000 sampai dengan tahun 2003 dapat dilihat pada tabel 2 berikut ini:

Dari tabel 2 dapat dilihat bahwa rata-rata harga ekspor lidah buaya per bulan tahun 2000 adalah 141,72 US\$/Ton, tahun 2001 rata-rata harga ekspor per bulan adalah 127,42 US\$/Ton, tahun 2002 ratarata harga ekspor per bulan adalah 150,13 US\$/Ton dan pada tahun 2003 rata-rata harga ekspor per bulan adalah 175,05 US\$/Ton.

Hal ini menunjukkan bahwa harga lidah buaya Kalimantan Barat di Malaysia rata-rata per bulan pada tahun 2002, 2003 mengalami kenaikkan bila dibandingkan dengan tahun 2000, dan 2001 mengalami penurunan.

Perkembangan Kurs (Nilai Tukar Mata Uang)

Nilai tukar kurs adalah harga mata uang suatu negara yang dibandingkan dengan mata uang negara lain. Dalam penelitian ini dilakukan perbandingan antara nilai Rupiah dengan Dollar Amerika karena ekspor lidah buaya Kalimantan Barat adalah ke negara Malaysia sehingga memggunakan ukuran kurs antara mata uang yang dapat diterima oleh semua pihak.

Dapat dilihat bahwa rata-rata kurs IndonesiaAmerika untuk ekspor lidah buaya pada tahun 2000 rata-rata per bulan adalah $\mathrm{Rp}$. 8.534,42, rata-rata kurs ekspor per bulan tahun 2001 adalah Rp. 10.265,67, pada tahun 2002 rata-rata per bulan adalah Rp. 9.352,00 dan pada tahun 2003 rata-rata per bulan adalah Rp. 8.574,08.

Dengan demikian dapat dilihat bahwa pada tahun 2000 nilai kurs rata-rata per bulan adalah Rp. $8.534,42$ dan nilai kurs tahun 2001 rata-rata per bulan adalah Rp. 10.265,67 mengalami kenaikkan serta pada tahun 2002 nilai kurs rata-rata per bulan adalah Rp. 9.352,00 mengalami penurunan, kemudian pada tahun 2003 nilai kurs per bulan adalah Rp. 8.574,08 mengalami penurunan lagi.

\section{HASIL PENELITIAN DAN PEMBAHASAN}

Analisis data pada model penelitian ini menggunakan metode ekonometrik dengan pendekatan kuadrat terkecil (Ordinary Least Squares/ OLS). Fungsi yang digunakan setelah dilakukan penggujian yang terbaik adalah:

$$
E_{t}=f\left(H_{t}^{f}, H_{t-1}^{f}, K, E_{t-1}\right)
$$

Dengan asumsi selera dan teknologi dianggap konstan. Sedangkan model regresi yang digunakan adalah model umum regesi linier, yaitu:

$$
E_{t}=\alpha_{1}+\alpha_{2} H_{t}^{f}+\alpha_{3} H_{t-1}^{f}, \alpha_{4} K+\alpha_{5} E_{t-1}+\epsilon_{t}
$$

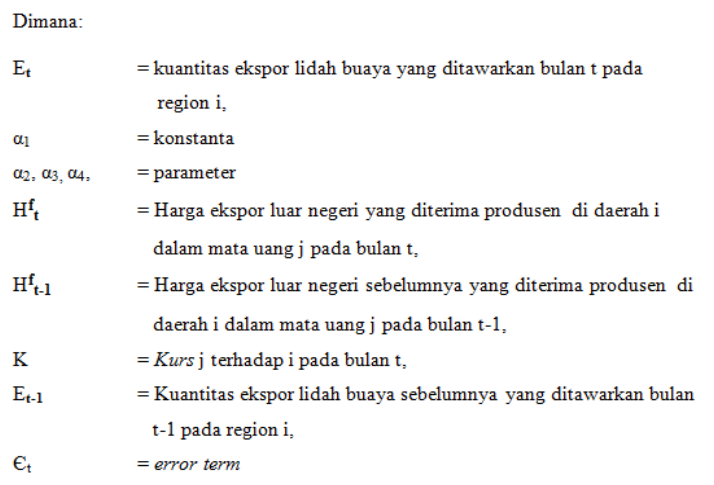

Setelah dilakukan analisis data dengan menggunakan program Shazam dengan pendekatan OLS diperoleh hasil estimasi sebagai berikut :

Sebelum menganalisis hasil estimasi dari fungsi ekspor maka akan dilihat terlebih dahulu apakah terjadi pelanggaran-pelanggaran asumsi klasik pada model yang akan dianalisis. Pelanggaran-pelanggaran yang dilihat adalah autokorelasi, heterokedastisitas, multikoleniaritas.

$$
\begin{aligned}
& E_{t}=(-14,400)+0,22656 \mathrm{H}^{\mathrm{f}}+(-0,11855) \mathrm{H}_{\mathrm{t}-1}^{\mathrm{f}}+0,00065008 \mathrm{~K}+0,71637 \mathrm{E}_{\mathrm{t}-1}
\end{aligned}
$$

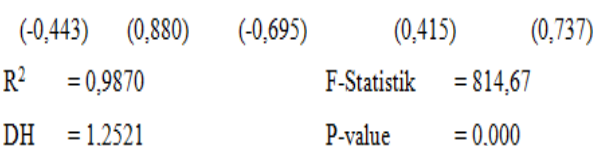

Untuk menguji apakah persamaan regresi tepat atau tidak sebagai penaksiran dari keadaan yang sebenarnya dilakukan pengujian kriteria ekonometrik. Uji kriteria ekonometri yang terdiri dari 3 macam pengujian, yaitu pengujian Multicolinearity, Heterokedastisity dan Autocorrelation.

Dari hasil uji pelanggaran asumsi, ditemukan pelanggaran asumsi yaitu heterokedastisitas dan multikoleniaritas. Salah satu cara untuk mengatasi heterokedastisitas dan multikoleniaritas adalah dengan metode Generaliz Least Square (GLS).

Estimasi terhadap fungsi ekspor yang telah diatasi dengan GLS adalah sebagai berikut:

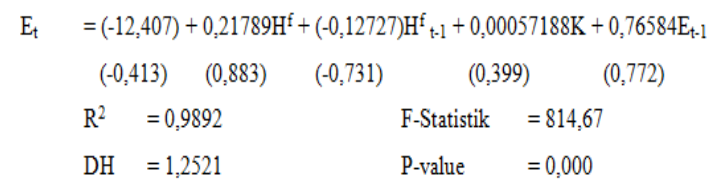


Analisis keragaman dapat dilihat pada tabel 3 berikut.

Tabel 3.

Analisis Keragaman Fungsi Ekspor lidah buaya ke Malaysia

\begin{tabular}{|c|c|c|c|}
\hline $\begin{array}{c}\text { Sumber } \\
\text { Keragaman }\end{array}$ & Jumlah Kuadrat & F-hitung & P-Value \\
\hline Regresi & 1657,6 & 814,670 & 0,000 \\
\hline Error & 21,873 & & \\
\hline Total & 1679,5 & & \\
\hline
\end{tabular}

Keterangan: $\alpha=10 \%$

Dari tabel 3 analisis keragaman fungsi ekspor lidah buaya ke Malaysia disimpulkan bahwa secara serempak memang benar variabel kuntitas ekspor $\left(E_{t}\right)$ dipengaruhi oleh variabel-variabel harga luar negeri $\left(\mathrm{H}^{\mathrm{f}}\right)$, harga luar negeri sebelumnya $\left(\mathrm{H}_{\mathrm{t}-1}^{\mathrm{f}}\right)$, kurs $(\mathrm{K})$ dan kuantitas ekspor sebelumnya $\left(\mathrm{E}_{\mathrm{t}-1}\right)$, hal ini dibuktikan dari lebih kecilnya P-Value dibandingkan dengan tingkat kesalahan $(\alpha)$ yang digunakan. Nilai $\mathrm{R}^{2}$ sebesar 0,9892 menunjukkan bahwa variasi variabel dependent ekspor $\left(E_{t}\right)$ 98,92\% dijelaskan oleh variabel-variabel independent harga luar negeri $\left(\mathrm{H}^{\mathrm{f}}\right)$, harga luar negeri sebelumnya $\left(\mathrm{H}_{\mathrm{t}-1}^{\mathrm{f}}\right)$, kurs $(\mathrm{K})$ dan kuantitas ekspor sebelumnya $\left(\mathrm{E}_{\mathrm{t}-1}\right)$. Sedangkan $0,89 \%$ dijelaskan oleh variabel-variabel lain yang tidak digunakan dalam penelitian ini.

Untuk lebih jelas estimasi model tersebut dapat dilihat pada tabel 4 berikut.

Tabel 4

Hasil Estimasi Fungsi ekspor lidah buaya ke Malaysia

\begin{tabular}{|c|c|c|c|}
\hline Variabel & Koefisien & t-hitung & P-Value \\
\hline $\mathrm{E}_{1}$ & 0,76584 & 7,967 & 0,000 \\
\hline $\mathrm{H}^{\mathrm{f}}$ & 0,21789 & 12,31 & 0,000 \\
\hline $\mathrm{H}_{\mathrm{f}-1}$ & $-0,12727$ & $-7,027$ & 0,000 \\
\hline $\mathrm{K}$ & 0,00057188 & 2,854 & 0,007 \\
\hline Konstan & $-12,407$ & $-2,976$ & 0,005 \\
\hline
\end{tabular}

Keterangan: $\alpha=10 \%$

Dari tabel 4 hasil estimasi fungsi ekspor lidah buaya ke Malaysia dapat dilihat bahwa kuantitas ekspor sebelumnya $\left(\mathrm{E}_{\mathrm{t}-1}\right)$ signifikan pengaruhnya terhadap kuantitas ekspor sesuai dengan yang dikatakan oleh Sukirno (1985:44) bahwa faktor-faktor yang menimbulkan kemunduran sektor ekspor adalah perubahan permintaan di luar daerah tersebut, habisnya cadangan kekayaan alam dan perubahan teknologi yang merubah posisi input. Sedangkan faktor-faktor yang mendorong ekspor adalah perkembangan jaringan pengangkutan, perkembangan pendapatan, permintaan dari daerah lain, perkembangan teknologi serta peran pemerintah pusat dan daerah dalam mengembangkan prasarana ekonomi maupun sosial di daerah yang bersangkutan.

Nilai koefisien kuantitas ekspor lidah buaya ke Malaysia adalah sebesar 0,76584. Artinya jika kuantitas ekspor sebelumnya naik 1 persen maka kuantitas ekspor lidah buaya akan naik sebesar 7,6584 persen. Hal ini menunjukkan bahwa adanya hubungan yang positif. Nilai koefisien harga luar negeri adalah sebesar 0,21789 persen. Artinya jika harga luar negeri naik 1 persen maka kuantitas ekspor akan naik 2,1789 persen. Nilai koefisien harga luar negeri sebelumnya adalah sebesar 0,12727 persen. Artinya jika harga luar negeri naik 1 persen maka kuantitas ekspor akan turun 1,2727 persen. Sedangkan nilai koefisien kurs adalah sebesar 0,00057188 persen. Artinya jika harga luar negeri naik 1 persen maka kuantitas ekspor akan naik 0,0057188 persen.

Sedangkan untuk melihat apakah hasil estimasi model penelitian bermakna secara teoritis (theoritically meaningful) dan ternyata secara statistik (statistically significant), akan dilakukan uji kriteria "a priori" ekonomi dan uji kriteria statistik.

Uji kriteria "a priori" ekonomi dilakukan dengan cara membandingkan kesesuaian tanda antara koefisien parameter regresi dengan teori yang bersangkutan. Jika tanda koefisien parameter regresi sesuai dengan prinsip-prinsip teori ekonomi, maka parameter tersebut telah lulus dari pengujian.

Dari hasil estimasi model regresi seperti pada table 5 didapat bahwa tanda koefisien parameter variabel independent baik pada hasil estimasi yang terdiri dari variabel harga luar negeri $\left(\mathrm{H}^{\mathrm{f}}\right)$, kurs $(\mathrm{K})$ Indonesia-Amerika dan kuantitas ekspor sebelumnya ketiga bertanda positif (+) sedangkan harga luar negeri sebelumnya $\left(\mathrm{H}_{\mathrm{t}-1}^{\mathrm{f}}\right)$ bertanda negatif $(-)$.

Untuk melihat apakah hasil estimasi model penelitian bermakna secara teoritis (theoritically meaningful) dan secara statistik (statistically significant), dilakukan uji kriteria "a priori" ekonomi dan uji kriteria statistik.

Uji kriteria statistik dilakukan berdasarkan pada prinsip-prinsip statistik yang terdiri dari pengujian ketepatan letak taksiran garis regresi, pengujian koefisien regresi secara simultan dan pengujian koefisien regresi secara parsial.

Uji ini ditunjukkan dengan nilai dari koefisien determinasi $\left(\mathrm{R}^{2}\right)$ yang nilainya antara nol sampai dengan satu $\left(0<\mathrm{R}^{2}<1\right)$. Untuk data sekunder, semakin nilai $\mathrm{R}^{2}$ (mendekati 1) maka estimasi model yang dihasilkan semakin mendekati keadaan yang 
sebenarnya (goodess of fit) atau menunjukan letak taksiran garis yang diperoleh telah tepat.

Hasil estimasi model mempunyai nilai $\mathrm{R}^{2}$ sebesar 0,9892. Ini mempunyai arti bahwa sebesar 98,92\% variasi variabel dependent kuantitas ekspor $\left(\mathrm{E}_{\mathrm{t}}\right)$ yang digunakan mampu dijelaskan variasi independent harga luar negeri $\left(\mathrm{H}^{\mathrm{f}}\right)$, harga luar negeri sebelumnya $\left(\mathrm{E}_{\mathrm{t}-1}\right)$, kurs dan kuantitas ekspor sebelumnya $\left(\mathrm{E}_{\mathrm{t}-1}\right)$ dalam model tersebut. Sedangkan sisanya sebesar $0,99 \%$ dijelaskan oleh variabel lain yang tidak digunakan dalam penelitian ini. Nilai $R^{2}$ model yang tinggi tersebut mampu memperlihatkan keadaan yang sebenarnya (goodness of fit) atau dapat dipercaya.

Pengujian koefisien regresi secara serentak bertujuan untuk mengetahui apakah semua variabel independent yang digunakan dalam estimasi model secara bersama-sama mempunyai pengaruh yang signifikan (berarti) terhadap variabel dependent. Pengujian ini dapat dilakukan dengan menggunakan uji Fisher (F-test) dengan cara membandingkan Fhitung dengan F-tabel.

Dengan menggunakan tingkat signifikan 1 persen $(\alpha=1 \%)$ serta derajat kebebasan (df) $\mathrm{N}_{1}=\mathrm{k}-$ 1 , sehingga $4-1=3$ dan $\mathrm{N}_{2}=\mathrm{n}-\mathrm{k}-1$, dan $48-3-$ $1=44$ maka diperoleh nilai kritis F-tabel sebesar 4,31 sedangkan nilai F-hitung adalah 814,67 sehingga dapat dikatakan bahwa F-tabel lebih kecil dari F-hitung (F-hitung = 4,31 > F - tabel = 814,67). Ini berarti bahwa semua variabel independent baik harga luar negeri, harga luar negeri sebelumnya, kurs dan kuantitas ekspor sebelumnya yang digunakan dalam etimasi model analisis ini adalah berpengaruh signifikan (berarti nyata) terhadap perubahan kuantitas ekspor Lidah Buaya Kalimantan Barat ke Malaysia.

Hal ini sesuai dengan teori siklus produksi (product cycle theory) dalam perdagangan internasional di mana siklus produksi terdiri dari 4 (empat) tahap. Tahap pertama adalah tahap inovasi atau produk baru, yakni awal mulanya suatu produk (dan proses produksinya) ditemukan atau dikembangkan. Tahap ini mempunyai beberapa ciri, yakni antara lain modal mengalami perubahan terus menerus.

Tahap kedua disebut tahap perluasan (pertumbuhan) volume produksi. Pada tahap ini permintaan baik yang bersumber dari dalam daerah sendiri atau dalam negeri maupun internasional meningkat, dan produk tersebut juga mulai di ekspor ke luar negeri.

Tahap ketiga adalah tahap kejenuhan pasar (maturity), yakni dimana produk dan proses produksinya telah mencapai kejenuhan pada tingkat yang tinggi dan market saturation meningkat.
Tahap keempat adalah di mana kegiatan produksi di daerah atau negara penghasil mengalami penurunan, karena persaingan yang semakin kuat dari dari daerah lain atau negara lain, yang pada akhirnya proses produksi seluruhnya pindah dari daerah atau negara penghasil ke daerah atau negara pembeli (Tambunan, 2001:130).

Pada teori siklus produksi (product cycle theory), tahap ketiga dan keempat hal tersebut belum terjadi dalam penelitian ekspor lidah buaya Kalimantan Barat ke Malaysia.

Pengujian koefisien regresi secara parsial bertujuan untuk mengetahui pengaruh masingmasing variabel bebas (independent variable) terhadap variabel tidak bebas (dependent variable).

Untuk mengetahui signifikansi estimasi koefisien dari masing-masing variabel bebas (independent variable) dapat dilihat dari nilai $\mathrm{p}$ value. Dengan melihat nilai $\mathrm{p}$-value pada tabel 5 dapat dinyatakan bahwa variabel harga luar negeri $\left(\mathrm{H}^{\mathrm{f}}\right)$ berpengaruh positif $(+)$ dan signifikan terhadap kuantitas ekspor Lidah Buaya Kalimantan Barat ke Malaysia pada tarap keyakinan $95 \%$ atau pada tingkat $5 \%(\alpha=5 \%)$ atau pada tingkat signifikan 5\% $(\alpha=5 \%)$. Hal ini dapat dilihat dari nilai $p$-value sebesar 0,000 dan masih lebih kecil kalau dibandingkan dengan tingkat signifikansi $(\alpha)$ yang digunakan $5 \%$ persen. Harga luar negeri sebelumnya berpengaruh positif dan signifikan terhadap kuantitas ekspor lidah buaya (Aloe Vera) pada taraf keyakian $95 \%$ atau pada tingkat $5 \%(\alpha=5 \%)$. Hal ini dapat dilihat pada nilai p-value sebesar 0,000 dan masih lebih kecil kalau dibandingkan dengan tingkat signifikansi $(\alpha)$ yang digunakan 5\%. Kurs berpengaruh positif dan signifikan terhadap kuantitas ekspor lidah buaya (Aloe Vera) hal ini dapat dilihat pada p-valuenya sebesar 0,005 pada taraf keyakian $95 \%$.

\section{SIMPULAN DAN SARAN}

Berdasarkan pada analisis dan hasil estimasi yang telah dilakukan, maka dapat diambil kesimpulan bahwa:

1. Lidah buaya (Aloe Vera) merupakan salah satu komoditi ekspor unggulan Kalimantan Barat baik secara komperatif maupun secara kompetitif. Ekspor Lidah Buaya Kalimantan Barat ditujukan pada banyak negara-negara Asia, khususnya negara Malasyia.

2. Ekspor Lidah Buaya Kalimantan Barat rata-rata berfluktuasi, kondisi ini disebabkan karena harga di pasar luar negeri selalu berubahberubah. Hal ini disebabkan karena tidak stabilnya permintaan terhadap ekspor Lidah Buaya Kalimantan Barat. 
3. Variabel harga luar negeri $\left(\mathrm{H}^{\mathrm{f}}\right)$, harga luar negeri sebelumnya $\left(\mathrm{H}_{\mathrm{t}-1}^{\mathrm{f}}\right)$, kurs $(\mathrm{K})$ dan kuantitas ekspor sebelumnya $\left(\mathrm{E}_{\mathrm{t}-1}\right)$ berpengaruh positif dan signifikan terhadap kuantitas ekspor Lidah Buaya Kalimantan Barat ke Malaysia.

4. Variabel Ekspor sebelumnya ( $\left.\mathrm{E}_{\mathrm{t}-1}\right)$ mempunyai pengaruh lebih besar terhadap kuantitas ekspor Lidah Buaya Kalimantan Barat ke Malaysia dan diikuti variabel harga luar negeri $\left(\mathrm{H}^{f}\right)$ dan kurs (K).

Saran

Berdasarkan kesimpulan di atas, maka saran yang dapat diberikan adalah sebagai berikut:

1. Perlu dilakukan analisis lanjutan pada komoditi Lidah Buaya mengenai variabel-variabel lain yang dapat mempengaruhi kuantitas ekspor.

2. Ekspor Lidah Buaya Kalimantan Barat perlu ditingkatkan sesuai dengan tujuan pembangunan sektor pertanian, selain untuk meningkatkan pendapatan petani, memperluas lapangan kerja dan kesempatan berusaha juga ditujukan untuk meningkatkan ekspor dengan cara antara lain dengan meningkatkan kegiatan intensifikasi, ekstensifikasi, diversifikasi dan peremajaan perkebunan yang sesuai dengan kondisi petani, tanah dan iklim. diversivikasi, intensivikasi pertanian. Peningkatan produktivitas melalui penciptaan varietas dengan adaptasi dan potensi hasil yang lebih tinggi serta perbaikan manajemen usahatani, kebijakan ekspor yang memadai untuk mendorong peningkatan produksi.

3. Kestabilan harga dan kurs perlu diperhatikan oleh pemerintah karena dengan adanya kestabilan harga dan kurs akan memudahkan dan mempelancar suatu kegiatan perdagangan.

4. Perlu dilakukan pengenalan dan bimbingan yang berkelanjutan mengenai usahatani Lidah Buaya dan diupayakan diversifikasi produk lidah buaya agar produksi dapat tertampung.

\section{DAFTAR PUSTAKA}

A.B., Roswita, 2000. Ekonomi Moneter, Teori, Masalah dan Kebijakkan, Edisi Ketiga, Penerbit Universitas Sriwijaya, Palembang.

Badan Pusat Statistik. Indikator Ekonomi, Desember 2004, Jakarta.

Badan Perencanaan Pembangunan Nasional (BAPPENAS). Perekonomian Indonesia Tahun 2004: Prospek dan Kebijakan, Desember 2003.

Bank Indonesia. Statistik Ekonomi Keuangan Indonesia, Vol.III No.12 Desember 2003.
Boediono, 1983. Ekonomi Internasional, Edisi Kedua, BPFE, Yogyakarta. 1995. Pengantar Ilmu Ekonomi: Ekonomi Internasional, Edisi Pertama, BPFE, Yogyakarta.

Chiang, Alpha C., 1984. Fundamental Methods of Mathematica Economics, Third Edition, Mc. Hill International Edition, Singapore.

Dinas Urusan Pangan, Aloe Vera Center Kalimantan Barat. 2003. Laporan Tahunan, Pontianak.

Douglas J, Evan, 1987. Managerial Economics Analisis and Strategi, Prentice Hall International Inc, New Jersey.

Dornbusch, dan Fischer, 1993. Makro Ekonomi, Edisi Keempat, Erlangga, Jakarta.

Feder. G, 1988. On Export and Ekonomic Growth, Jurnal of Development Economics. No.1-2.

Fadhila, Tina, 1998. Analisis Faktor-Faktor yang Mempengaruhi Permintaan Kentang di Kotamadya Banda Aceh, Skripsi, Fakultas Ekonomi, Universitas Syiah Kuala, Banda Aceh, Tidak dipublikasikan.

Grubel, Herbert G, 1981. International Ekonomics, Revised Edition, Richard D. Irwin, Inc, Ilionis.

Hill, Hal, 2001. Ekonomi Indonesia, Edisi Kedua, PT. Raja Grafindo Persada, Jakarta.

Jhingan, M.L., 1996. Ekonomi Pembangunan, PT. Raja Grafindo Persada, Jakarta.

Joesron, Tati Suhartati, dan Fathorrozi, 2002. Teori Ekonomi Mikro, Edisi Pertama, Salemba Empat, Jakarta.

Khalifah, Noor Aini, (1992). International Trade of the East Asian Economic Caucus, Jurnal Ekonomi Malaysia $25: 19-45$.

Mankiw, N Gregory, 2000. Teori Makro Ekonomi, Edisi Keempat, Erlangga, Jakarta.

Nicholson. Walter, 1989. Teori Ekonomi Mikro, Edisi Kedua, CV. Rajawali, Jakarta.

Nopirin, 1996. Ekonomi Internasional, Edisi Ketiga, BPFE, Yogyakarta.

Ramanathan, Ramu, 1997. Introductory Econometrics With Applications, Fourth Edition, The Dryden Press, Orlando.

Satria, Arif, (2003). Pertanian Indonesia Dalam Perspektif Industrialisasi dan Perdagangan Bebas: Suatu Pendekatan Teoritik-Empirik, Jurnal Pertanian Indonesia, Volume 7.2.

Sahlan, Rizaudin, (2002). Hubungan Sebab-Akibat antara Eksport Mengikuti Sektor dan Pertumbuhan Ekonomi di Negara ASEAN Terpilih, Jurnal Ekonomi Malaysia, 36.

Salvatore, Dominik, 1997. Ekonomi Internasional, Edisi Kelima, Jilid Satu, Erlangga, Jakarta.

Shamsudin, Nasir dan Tek Ann, Chew serta Rosdi, Mat Lani, 1992. An Econometric Analisis of 
Cocoa Prices: A Structural Approach. Jurnal Ekonomi Malaysia, 25:3-17.

Simamora, Tuana, 1990. Teori Ekonomi Makro, Penerbit Bina Alumni, Indonesia, Medan.

Sujana, 1992. Metoda Statistika, Edisi Kelima, Tarsito, Bandung.

Sukirno, Sadono, 1985. Ekonomi Pembangunan: Proses, Masalah dan Dasar Kebijakan, LPFE UI, Jakarta.

Makroekonomi, 1994. Pengantar Teori Grafindo Persada, Jakarta.

Sumodiningrat, Gunawan, 1996. Ekonometrika, Edisi Pertama, BPFE, Yogyakarta.

Suparmoko, 1990. Ekonomi Pembagunan, Edisi Kedua, BPFE, Yogyakarta.

Syahrir, 1992. Analisis Ekonomi Indonesia, Gramedia, Jakarta.

Todaro, Michael, P., 2000. Pembangunan Ekonomi Di Dunia Ketiga, Edisi Keenam, Erlangga, Jakarta.

Tambunan, Tulus T.H., 2002. Transformasi Ekonomi di Indonesia, Teori dan Penemuan Empiris, Edisi Pertama, Penerbit Salemba Empat, Jakarta. 